\title{
Breeding Enhancement of Musca domestica L. 1758: Egg Load as a Measure of Optimal Larval Density
}

\author{
Idriss Hamidou Leyo ${ }^{1, *(\mathbb{C})}$, Zakari Moussa Ousmane ${ }^{1}$, Gregoire Noël ${ }^{2}\left(\mathbb{C}\right.$, Frédéric Francis ${ }^{2}$ (1) \\ and Rudy Caparros Megido ${ }^{2}$ (i) \\ 1 Ecole Doctorale Science de la Vie et de Terre EDSVT, Faculté d'Agronomie, Université Abdou Moumouni de Niamey, \\ Niamey BP 10960, Niger; o.zakari@gmail.com \\ 2 Entomologie Fonctionnelle et Évolutive, Terra, Gembloux Agro-Bio Tech, Liège-Université, Passage des \\ Déportés 2, 5030 Gembloux, Belgium; gregoire.noel@uliege.be (G.N.); frederic.francis@uliege.be (F.F.); \\ r.caparros@uliege.be (R.C.M.) \\ * Correspondence: ihamidouleyo@outlook.com
}

Citation: Hamidou Leyo, I.; Moussa Ousmane, Z.; Noël, G.; Francis, F.; Caparros Megido, R. Breeding Enhancement of Musca domestica L. 1758: Egg Load as a Measure of Optimal Larval Density. Insects 2021, 12, 956. https://doi.org/10.3390/ insects 12110956

Academic Editor: David Rivers

Received: 7 September 2021

Accepted: 12 October 2021

Published: 20 October 2021

Publisher's Note: MDPI stays neutral with regard to jurisdictional claims in published maps and institutional affiliations.

Copyright: (c) 2021 by the authors. Licensee MDPI, Basel, Switzerland. This article is an open access article distributed under the terms and conditions of the Creative Commons Attribution (CC BY) license (https:// creativecommons.org/licenses/by/ $4.0 /)$.
Simple Summary: The amount of waste produced by the population creates general health problems in terms of public health and hygiene. In recent years the common housefly (Musca domestica L. 1758) has been widely used in the treatment of organic wastes. This study aims to assess the effect of egg loading of the common housefly on maggot development and waste reduction. To do this, several housefly egg loads were incubated on three different substrates. This study indicated that larval biomass, larval number, the survival rate from egg hatching until the last larval instar and substrate rate reduction of Musca domestica are affected by the egg load, substrate type and their interaction. It was found that under the same nutritional conditions, the yield of housefly larvae, the number of larvae and the reduction of substrates increased with increasing egg load.

Abstract: The amount of waste produced by the population creates general health problems in terms of public health and hygiene. In recent years the common housefly (Musca domestica L. 1758; Dipteran: Muscidae) has been widely used in the treatment of organic wastes. This study aims to assess the effect of egg loading of the common housefly on maggot development and waste reduction. Housefly larvae were reared at four egg loads $(1.25,2.5,5,10 \mathrm{mg})$ under three different diets (wheat bran, millet bran, cow dung). Two-factor ANOVA $(\alpha=0.05)$ was used to test the effect of two fixed factors (egg load and substrate) on larval biomass, the survival rate from egg hatching until the last larval instar, number of larvae and substrate reduction rate. The comparison of means based on Duncan's test was performed to compare the means of the different variables measured. Principal component analysis (PCA) was used to determine the relationship between the measured variables (larval biomass, the survival rate from egg hatching until the last larval instar, number of larvae, and substrate reduction rate) on the discrimination of the egg load factor. The results showed that under the same nutritional conditions, the yield of housefly larvae, the number of larvae and the reduction of substrates increased with increasing egg load. Indeed, at each of three substrates, the rearing egg load of $10 \mathrm{mg}$ resulted in the maximum larval yield, maximum number of larvae, and maximum substrate reduction rate. At this optimum load, wheat bran generated greater biomass, greater number of larvae and greater reduction of substrate compared to millet bran and cow dung. The egg load as a whole had no effect on the survival rate from egg hatching until the last larval instar, unlike substrate type. The high egg load for the survival rate (from egg hatching until the last larval instar) for millet bran was 1.25 while there was no difference for the other two substrates. These results can help to make the waste treatment process efficient with the subsequent production of a large larval biomass that can serve as added value in animal feed. The egg load of $10 \mathrm{mg}$ and the wheat bran were superior respectively to the other egg load and substrates type for all parameters tested excepted for the survival rate (from egg hatching until the last larval instar). Ours study indicated that larval biomass, larval number, egg viability and substrate rate reduction of Musca domestica are affected by the egg load, substrate type and their interaction. 


\section{Introduction}

Since the start of the 19th century, the global urban population has grown from 220 million to over 4 billion. Consequently, the amount of waste produced has multiplied 20 -fold, bringing the amount of household waste to 2.01 billion ton per year today and it is expected to grow to 3.40 billion ton by 2050 [1]. For example, during 2016, 174 million ton of household waste was generated in sub-Saharan Africa (currently 400 million inhabitants), representing about $0.46 \mathrm{~kg}$ of waste per capita per day [2,3]. In particular, Niger is experiencing strong demographic pressure, with a population estimated at 25 million inhabitants in 2020 [4] and a population growth rate of 3.87\%, which is the highest globally. The capital of Niger, Niamey, is the most populous city in Niger, with 1,336,000 inhabitants, of which approximately $43 \%$ practiced agriculture in 2008. This strong growth of the urban community of Niamey (UCN) has led to the emergence of agriculture in urban and peri-urban areas. In 2015, animal herds in Niamey, capital of Niger, were estimated at around 105,212 TLU (tropical livestock units) [5].

Urbanization of the UCN increases the amount of waste generated each year. The citizens of UCN produce 1000 tons of waste generated daily [6]. This quantity of waste produced by the population creates widespread concerns in terms of public health and hygiene. Particular issues include restricted flow of runoff water, blocked gutters, and blocked wastewater ducts, including solid waste ducts. The accumulation of this waste creates favorable conditions for the development of vectors of diseases, including malaria and cholera. In parallel, pestilential odors arise, which considerably hamper the use of public spaces. Consequently, the aesthetic appeal of the city is masked by pollution, piles of rubbish extending from dumpsites and obstructing streets [2,3]. The governments should develop solutions to manage these various complex challenges.

Typical methods used for waste treatment include incineration, composting, and anaerobic digestion [7]. However, several studies, focus has been placed on using insects in the bioconversion of waste as a solution for recycling waste and reducing food waste [8-10]. This alternative approach allows organic waste to be recycled, and parallel converting several tons of organic waste to protein-rich larval biomass [11]. This larval biomass can be used in both human food and animal feed. Maggot meal could partially or totally replace fishmeal in animal feed, particularly poultry feed, with no negative effects [9,11-20]. The recycling of waste and the production of protein are two of many benefits in using insects for waste treatment. The use of insects also generates a residue that is rich in minerals, which can be valorized as a quality bio-fertilizer to improve soil quality, enhance crop yield, and reduce the use of chemical fertilizers [21-25]. Furthermore, this residue can be used to produce secondary industrial compounds (e.g., biofuel, lubricants, pharmaceuticals, dyes) [26].

Several fly species are used for the organic recycling of waste, including Hermetia illucens (L. 1758), Musca domestica (L. 1758), Musca autumnalis (De Geer 1776), Lucilia sericata (Meigen 1826) and Sacrophaga carnaria (L. 1758) [14,27-31]. M. domestica, commonly known as housefly, is the species of fly that is most widely used in organic waste recycling. This cosmopolitan fly has the advantage of being able to grow in a broad spectrum of wastes and has a shorter development cycle than other species in Africa [32-42]. There are various methods used in maggot production systems. The first production system of housefly maggot is based on the exposure of substrates (i.e., pig manure, poultry manure, cattle manure, slaughterhouse waste) placed in a container (bucket, calabash, pot...), to attract adults for oviposition. A few days later, the substrate is sifted to extract mature maggots, which are either sun dried or given fresh to the animals. On the other hand, the maggot production system is based on the rearing of adult fly colonies in cages with various sizes. These fly colonies are placed in production rooms maintained under given conditions of 
temperature, relative humidity, and photoperiod. For more information on the maggot production method, the literature review of [43] gives us a better global overview on the fly maggot production method.

In order to take advantage and to harness the capacity of the housefly to reduce waste material into high quality animal protein, this species needs to be mass-reared or farmed. The housefly intensive farming is not very different to intensive farming of livestock. Many factors are limiting the mass-rearing of housefly and often referred to as density-dependent processes, temperature, and substrate [44-47]. While a few studies have looked on different larval densities on various substrates $[27,37,44,48]$, there are no published studies that investigated simultaneously the effect of several larval density of housefly and several substrates on the biological parameters of housefly.

It has been reported that housefly larvae have a high crude protein content (40 to $60 \% \mathrm{DM}$ ) and lipid content (9 to 25\% DM) [49] and lysine and methionine (the two most limiting essential amino acids) were found to be higher in maggot meal than in fish meal and other conventional protein sources [50]. It is also show that the fatty acid profile of housefly larvae is suitable for broiler growth [51]. It was reported that the bioconversion of waste with housefly larvae offered a digested residue which can be used as a quality biofertilizer to improve soil quality, increase crop yields and reduce the use of chemical fertilizers [43]. In addition, this digested residue can be sold and thus create revenue [52]. All these advantages linked to the waste management using the housefly may well benefit poor countries as Niger which has low financial means and a population with strong demographic growth generating more and more important quantities of waste and where poultry farming is an activity practiced by more than $80 \%$ of the population in Niger [53].

The current study aims to evaluate the impact of different eggs load of M. domestica on maggot development and waste reduction, using three different substrates for larval development. The hypothesis is that waste reduction and larval yield increase with egg load regardless of the larval development substrate used.

\section{Materials and Methods}

\subsection{House Fly Colony}

Insects used in this experiment originated from the mass breeding of M. domestica at the Faculty of Agronomy in Abdou Moumouni University (Niamey, Niger). Five breeding cages (75 × $75 \times 115 \mathrm{~cm}$ BugDorm, Mega View Science, Taichung, Taiwan) were used to maintain breeding. Each cage contained 25,000 reared M. domestica pupae corresponding to a storage density of approximately $2.8 \mathrm{~cm}^{3}$ per fly [40]. Cotton soaked in a mixture of powdered milk and granulated sugar (ratio 1:1), and sponges soaked in sweet water placed in plastic containers were used as food for the adults. The cages were placed in a room with photoperiod of $12 \mathrm{~h}$ light and $12 \mathrm{~h}$ dark (12:12 L:D), temperature of $25 \pm 2{ }^{\circ} \mathrm{C}$, and relative humidity $(\mathrm{RH})$ of $60-70 \%[40,54]$.

\subsection{Effect of Egg Load on Larval Productivity}

Five days after adult emergence, plastic containers ( $83 \mathrm{~mm}$ diameter and $3 \mathrm{~cm}$ height) containing a mixture of water, wheat bran, and granulated sugar $(2: 1 ; 70 \%$ moisture) covered with filter paper (grade: 50, circular, porosity: $2.7 \mu \mathrm{m}$; Whatman, La Chapellesur-Erdre, France) were placed in colony cages as spawning medium [40]. Flies were allowed to lay eggs for $8 \mathrm{~h}$ ( 8.00 to $16.00 \mathrm{~h}$ ). Filter paper was used just to prevent flies from laying eggs on the mixture of fermented wheat bran and granulated sugar as spawning medium and allow easy collection of eggs. The eggs were weighed on a balance $(0.001 \mathrm{~g}$, Sartorius, Goettingen, Germany) using a fine brush in the breeding room where humidity is kept relatively high $(60-70 \% \mathrm{RH})$ to avoid desiccation of the eggs and water loss from larval medium [55]. Four different egg loads (i.e., 1.25, 2.5, 5 and $10 \mathrm{mg}$ ), similar to egg load used on cattle manure by [37], were tested on three different substrates: millet bran, wheat bran, and cow dung. Millet bran and wheat bran are the less expensive or even free substrate from household waste and these substrates are the most accessible and available 
products in UCN. Cow dung is the most common materials found in UCN. Twenty grams of dry substrate was used and the humidity of the different substrates was kept at $70 \%$ by adding tap water. Each egg load was incorporated in the substrate per replicate $(n=3)$. All maggots were reared in plastic containers $(17.20 \times 11.50 \times 6.00 \mathrm{~cm}$, AVA, Temse, Belgium $)$ covered with a transparent lid with a fine tissue for ventilation. Containers were randomly arranged at half-height on a board. The experiment was implemented under the same environmental conditions as the rearing of adults $\left(26^{\circ} \mathrm{C} \pm 2{ }^{\circ} \mathrm{C} ; 60-70 \% \mathrm{RH}\right.$ and $\left.12: 12 \mathrm{~L}: \mathrm{D}\right)$.

\subsection{Evaluation}

Five days after placing the eggs in the different substrates, the larval biomass, larval number, egg viability (EV), and final substrates (substrate residue after larval extraction) were measured by replicate. Larval biomass was weighed on a balance $(0.001 \mathrm{~g}$, Sartorius, Goettingen, Germany) and the larval number (LN) was counted per replicate. To calculate egg viability (EV), the number of eggs in each egg load was counted beforehand: the eggs were placed in petri dishes $(90 \mathrm{~mm})$ half-filled with water and sifted using filter paper to separate them for counting. Survival larval rate until the last larval instar (SR) was calculated by dividing the number of larvae by the number of eggs corresponding to each egg load incorporated per replicate. The final substrate of each replicate was dried in the oven at $70^{\circ}$ for $24 \mathrm{~h}$ and weighed. The reduction in substrate rate (SRR) of each replicate was calculated following the method described by [56] used for Hermetia illucens: substrate reduction rate $(\mathrm{SRR})=[($ distributed substrate $(\mathrm{g})-$ residual substrate $(\mathrm{g})) /$ distributed substrate $(\mathrm{g})] \times 100$.

\subsection{Statistical Analyses}

All statistical analyses and graphics were performed on $\mathrm{R}$ version 4.0.3 environment [57]. Two-factor ANOVA $(\alpha=0.05)$ was used to test the effect of two fixed factors (egg load and substrate) on larval biomass, egg viability, number of larvae and substrate reduction rate. The comparison of means based on Duncan's test was performed to compare the means of the different variables measured (larval biomass, egg viability, number of larvae, and substrate reduction rate) on the different egg loads according to the different substrates as well as to compare the means of the different substrates of these same variables according to each egg load. Principal component analysis (PCA) was used to determine the relationship between the measured variables (larval biomass, egg viability, number of larvae, and substrate reduction rate) on the discrimination of the egg load factor (egg load). The following $\mathrm{R}$ packages agricolae and FactoMineR were used during analyses [58,59].

\section{Results}

Effect of Substrate Type and Egg Load of Musca domestica on Maggot Development and Waste Reduction

Two-way analysis of variance (Table 1) shows that larval biomass, larval number, and substrates rate reduction were strongly influenced by the substrate type and egg load as well as the interaction of the two factors. Overall, egg load has no effect on the survival rate (from egg hatching until the last larval instar; SR). However, substrate type and its interaction with egg load have a significant effect on egg viability.

The ANOVA results (Table 2-vertical comparison) show that the larval biomass is influenced by the egg loads for each substrate. For all three substrates, the highest biomass is obtained with an egg load of $10 \mathrm{mg}$. At this high egg load $(10 \mathrm{mg})$, wheat bran generated a higher larval biomass than the other two substrates. It was found that egg viability was influenced by egg load only for the millet bran substrate, whose optimal average was obtained at the egg load of $1.25 \mathrm{mg}(95.00 \pm 5.00 \%)$. The number of larvae measured was also significantly influenced by the egg loads for each level of substrate. The high average larval number was obtained with the egg load of $10 \mathrm{mg}$ (wheat bran $=156.66 \pm 1.52$, cow dung $=155.00 \pm 3.46$, millet bran $=150.00 \pm 2.00$ ). With respect to substrate reduction by maggots, the egg load had a significant effect for each substrate as the $10 \mathrm{mg}$ egg load 
provided the highest reduction rate with an average of $26.00 \pm 1.00,24.33 \pm 0.57$, and $2233 \pm 058$ for wheat bran, millet bran, and cow dung, respectively.

Table 1. Summary of the two-factor ANOVA test on the influence of egg load, substrate, and their interaction on the observed parameters.

\begin{tabular}{ccccc}
\hline Parameters & Factors & Df & F Value & $p$-value \\
\hline & Egg load & 3 & 1278.95 & $p<0.001$ \\
Biomass & Substrates & 2 & 109.36 & $p<0.001$ \\
& Egg load $\times$ Substrates & 6 & 21.29 & $p<0.001$ \\
\hline \multirow{2}{*}{ Survival rate } & Egg load & 3 & 0.63 & 0.600 \\
& Substrates & 2 & 16.31 & $p<0.001$ \\
& Egg load $\times$ Substrates & 6 & 4.194 & 0.005 \\
Larval number & Egg load & 3 & 3496.44 & $p<0.001$ \\
& Substrates & 2 & 20.05 & 0.001 \\
Substrate rate & Egg load $\times$ Substrates & 6 & 3.16 & 0.019 \\
reduction & Substrates & 3 & 453.10 & $p<0.001$ \\
& Egg load $\times$ Substrates & 2 & 58.38 & $p<0.001$ \\
\hline
\end{tabular}

The $p$-values in italic indicate significant tests $(p<0.05)$.

Table 2. ANOVA of biological parameters inside different substrates as a function of egg load and between the different substrates.

\begin{tabular}{|c|c|c|c|c|c|}
\hline Parameters & Egg Lad (mg) & Millet Bran & Wheat Bran & Cow Dung & Statistical Analysis \\
\hline $\begin{array}{l}\text { Biomass } \\
(\mathrm{mg})\end{array}$ & $\begin{array}{c}1.25 \\
2.5 \\
5 \\
10 \\
\text { Statistical analysis }\end{array}$ & $\begin{array}{c}412.67 \pm 11.93 \mathrm{c}(\mathrm{b}) \\
506.00 \pm 95.39 \mathrm{c}(\mathrm{c}) \\
1267.00 \pm 146.24 \mathrm{~b}(\mathrm{~b}) \\
2194.67 \pm 61.04 \mathrm{a}(\mathrm{c}) \\
p<0.001 ; \mathrm{Df}=3 ; \\
\mathrm{F}=238.70\end{array}$ & $\begin{array}{c}488.33 \pm 9.60 \mathrm{~d}(\mathrm{~b}) \\
855.33 \pm 49.90 \mathrm{c}(\mathrm{b}) \\
1712.33 \pm 184.85 \mathrm{~b}(\mathrm{a}) \\
3240.00 \pm 76.21 \mathrm{a}(\mathrm{b}) \\
p<0.001 ; \mathrm{Df}=3 \\
\mathrm{~F}=421.90\end{array}$ & $\begin{array}{c}396.33 \pm 23.02 \mathrm{~d}(\mathrm{a}) \\
726.33 \pm 17.09 \mathrm{c}(\mathrm{a}) \\
1281.33 \pm 1.52 \mathrm{~b}(\mathrm{~b}) \\
2458.66 \pm 63.10 \mathrm{a}(\mathrm{a}) \\
p<0.001 ; \mathrm{Df}=3 \\
\quad \mathrm{~F}=2047.00\end{array}$ & $\begin{array}{c}p<0.001 ; \mathrm{Df}=2 ; \mathrm{F}=28.35 \\
p=0.001 ; \mathrm{Df}=2 ; \mathrm{F}=23.63 \\
p=0.011 ; \mathrm{Df}=2 ; \mathrm{F}=10.37 \\
p<0.001 ; \mathrm{Df}=2 ; \mathrm{F}=196.80\end{array}$ \\
\hline $\begin{array}{c}\text { Survival } \\
\text { rate }(\%)\end{array}$ & $\begin{array}{c}1.25 \\
2.5 \\
5 \\
10 \\
\text { Statistical analysis }\end{array}$ & $\begin{array}{c}95.00 \pm 5.00 \mathrm{a}(\mathrm{a}) \\
75.00 \pm 1.00 \mathrm{~b}(\mathrm{~b}) \\
77.33 \pm 10.69 \mathrm{~b}(\mathrm{~b}) \\
75.33 \pm 6.65 \mathrm{~b}(\mathrm{~b}) \\
p=0.018 ; \mathrm{Df}=3 \\
\mathrm{~F}=6.03\end{array}$ & $\begin{array}{l}93.33 \pm 5.77 \mathrm{a} \mathrm{(a)} \\
91.33 \pm 7.63 \mathrm{a}(\mathrm{a}) \\
97.00 \pm 1.73 \mathrm{a}(\mathrm{a}) \\
98.00 \pm 1.00 \mathrm{a}(\mathrm{a}) \\
p=0.363 ; \mathrm{Df}=3 \\
\mathrm{~F}=1.22\end{array}$ & $\begin{array}{l}85.00 \pm 10.00 \mathrm{a}(\mathrm{a}) \\
94.66 \pm 10.40 \mathrm{a}(\mathrm{a}) \\
93.66 \pm 4.50 \mathrm{a}(\mathrm{a}) \\
96.66 \pm 2.30 \mathrm{a}(\mathrm{a}) \\
P=0.322 ; \mathrm{Df}=3 ; \\
\mathrm{F}=1.36\end{array}$ & $\begin{array}{c}p=0.272 ; \mathrm{Df}=2 ; \mathrm{F}=1.63 \\
p=0.037 ; \mathrm{Df}=2 ; \mathrm{F}=5.98 \\
p=0.025 ; \mathrm{Df}=2 ; \mathrm{F}=7.24 \\
p<0.001 ; \mathrm{Df}=2 ; \mathrm{F}=28.74\end{array}$ \\
\hline $\begin{array}{l}\text { Larval } \\
\text { number }\end{array}$ & $\begin{array}{c}1.25 \\
2.5 \\
5 \\
10 \\
\text { Statistical analysis }\end{array}$ & $\begin{array}{c}19.00 \pm 1.00 \mathrm{~d}(\mathrm{a}) \\
30.66 \pm 1.51 \mathrm{c}(\mathrm{b}) \\
63.33 \pm 8.50 \mathrm{~b}(\mathrm{~b}) \\
150.00 \pm 2.00 \mathrm{a}(\mathrm{b}) \\
p<0.001 ; \mathrm{Df}=3 ; \\
\mathrm{F}=534.90\end{array}$ & $\begin{array}{c}19.66 \pm 0.57 \mathrm{~d}(\mathrm{a}) \\
37.00 \pm 2.00 \mathrm{c}(\mathrm{a}) \\
78.01 \pm 2.05 \mathrm{~b}(\mathrm{a}) \\
156.66 \pm 1.52 \mathrm{a} \mathrm{(a)} \\
p<0.001 ; \mathrm{Df}=3 \\
\mathrm{~F}=4187.00\end{array}$ & $\begin{array}{c}20.00 \pm 1.00 \mathrm{~d}(\mathrm{a}) \\
38.66 \pm 1.52 \mathrm{c}(\mathrm{a}) \\
75.33 \pm 2.51 \mathrm{~b}(\mathrm{a}) \\
155.00 \pm 3.46 \mathrm{a} \mathrm{(a)} \\
p<0.001 ; \mathrm{Df}=3 \\
\mathrm{~F}=1978.00\end{array}$ & $\begin{array}{c}p=0.422 \mathrm{Df}=2 ; \mathrm{F}=1.00 \\
p=0.001 ; \mathrm{Df}=2 ; \mathrm{F}=20.91 \\
p=0.030 ; \mathrm{Df}=2 ; \mathrm{F}=6.64 \\
p=0.038 ; \mathrm{Df}=2 ; \mathrm{F}=5.99\end{array}$ \\
\hline $\begin{array}{l}\text { Substrate } \\
\text { rate } \\
\text { reduction } \\
(\%)\end{array}$ & $\begin{array}{c}1.25 \\
2.5 \\
5 \\
10 \\
\text { Statistical analysis }\end{array}$ & $\begin{array}{c}05 \pm 0.01 \mathrm{~d}(\mathrm{a}) \\
12.66 \pm 1.52 \mathrm{c}(\mathrm{a}) \\
18.66 \pm 2.08 \mathrm{~b}(\mathrm{~b}) \\
24.33 \pm 0.57 \mathrm{a}(\mathrm{b}) \\
p<0.001 ; \mathrm{Df}=3 ; \\
\mathrm{F}=102.90\end{array}$ & $\begin{array}{l}05.33 \pm 0.57 \mathrm{~d}(\mathrm{~b}) \\
15.00 \pm 1.00 \mathrm{c}(\mathrm{b}) \\
23.00 \pm 1.02 \mathrm{~b}(\mathrm{~b}) \\
26.00 \pm 1.00 \mathrm{a}(\mathrm{c}) \\
p<0.001 ; \mathrm{Df}=3 ; \\
\quad \mathrm{F}=162.10\end{array}$ & $\begin{array}{l}02.00 \pm 1.01 \mathrm{~d}(\mathrm{a}) \\
07.66 \pm 1.52 \mathrm{c}(\mathrm{a}) \\
15.66 \pm 0.57 \mathrm{~b}(\mathrm{a}) \\
22.33 \pm 0.58 \mathrm{a}(\mathrm{a}) \\
p<0.001 ; \mathrm{Df}=3 ; \\
\quad \mathrm{F}=239.00\end{array}$ & $\begin{array}{l}p=0.006 ; \mathrm{Df}=2 ; \mathrm{F}=13.00 \\
p=0.001 ; \mathrm{Df}=2 ; \mathrm{F}=22.29 \\
p=0.005 ; \mathrm{Df}=2 ; \mathrm{F}=14.20 \\
p=0.002 ; \mathrm{Df}=2 ; \mathrm{F}=18.20\end{array}$ \\
\hline
\end{tabular}

Italic value indicates significant tests $(p<0.05)$ and the brackets for the letters correspond to horizontal tests. The letters are from the Duncan comparison at threshold $\alpha=0.05$.

Larval biomass was significantly influenced by substrates for each egg load considered (Table 2-horizontal comparison). For each corresponding egg load, wheat bran provided the highest larval biomass with an average of $488.33 \pm 9.60 \mathrm{mg}, 855.33 \pm 49.90 \mathrm{mg}$, $1712.33 \pm 184.85 \mathrm{mg}$, and $3240.00 \pm 76.26 \mathrm{mg}$ for the 1.25, 2.5, 5, and $10 \mathrm{mg}$ egg load, respectively. SR was not significantly $(p=0.272)$ influenced by the substrates for the $1.25 \mathrm{egg}$ load in contrast to the other egg loads. The $10 \mathrm{mg}$ egg load had recorded the highest SR that was essentially identical to the wheat bran and cow dung with an average of $98.00 \pm 1.00$ and $96.66 \pm 2.30 \%$, respectively. While the highest SR for millet bran $(95.00 \pm 5.00 \%)$ was obtained with the egg load of $1.25 \mathrm{mg}$. Regarding the number of larvae, there was no significant difference $(p=0.422)$ between the substrates for the $1.25 \mathrm{mg}$ egg load. Nevertheless, the $10 \mathrm{mg}$ egg load resulted in a significantly different average 
number of larvae between the three substrates. At this highest egg load (10 mg), the average number of larvae was $156.66 \pm 1.52,155.00 \pm 3.456$, and $150.00 \pm 2.00$, respectively, for wheat bran, cow dung, and millet bran. For the ability of maggots to reduce their feeding substrates, there was a significant difference between substrates for each egg load considered. At the level of each egg load, wheat bran rerecorded the highest reduction rate with an average of $05.33 \pm 0.57,15.00 \pm 1.00,23.00 \pm 1.02$, and $26.00 \pm 1.00 \%$ for the 1.25 , $2.5,5$, and $10 \mathrm{mg}$ egg load, respectively.

The correlation circle obtained from the PCA based on the first two axes explains the relationship between the measured variables (Figure 1A) and shows the discrimination of egg load (Figure 1B) according to the measured variables. The first two dimensions explain $95.7 \%$ of the total information, with $70.3 \%$ for dimension 1 and $25.4 \%$ for dimension 2 (Figure 1A). SR is positively correlated with dimension 2 (correlation coefficient greater than 0.5), while larval biomass (Biom), number of larvae (LN) and substrate reduction (SRR) are positively correlated with dimension 1 (correlation coefficient greater than 0.5 ) and are also positively correlated with each other (Figure 1A). However, SR is an independent variable from the other three variables (Figure 1A). The dimension 2 (Figure 1B) discriminates well the egg loads according to its increasing order. The four egg loads were clearly differentiated from each other, the $1.25 \mathrm{mg}$ and $2.5 \mathrm{mg}$ loads are significantly close to each other, while the $10 \mathrm{mg}$ load is well distinguished from all other egg loads (Figure 1B). The $5 \mathrm{mg}$ load is closer to the $2.5 \mathrm{mg}$ and $10 \mathrm{mg}$ loads than to the $1.25 \mathrm{mg}$ load.
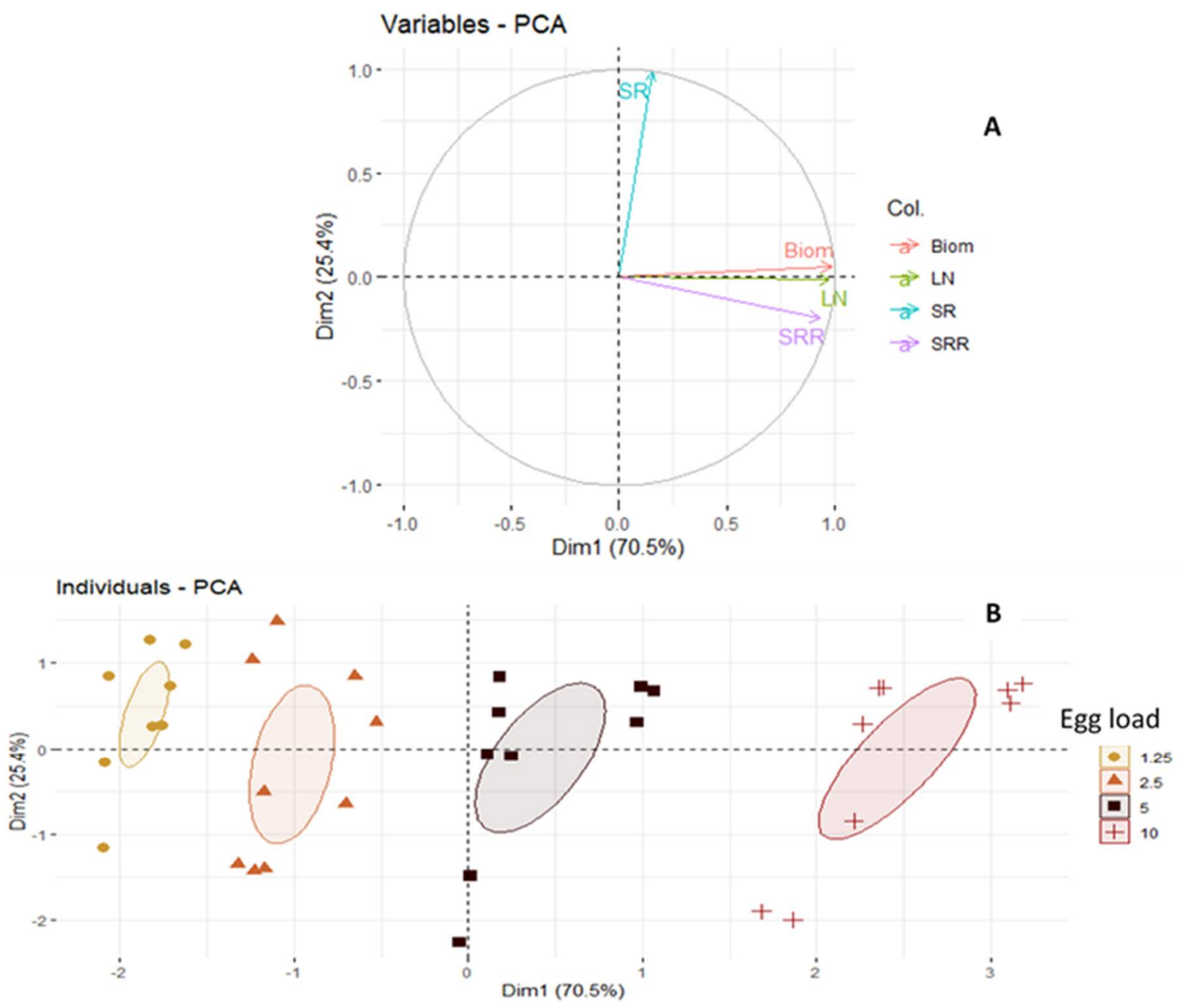

Figure 1. (A) Circle of correlation of variables. (B) Graphical representation of individuals as a Figure. Biom: biomass; LN: larval number; SR: survival rate; SRR: substrate reduction rate. 


\section{Discussion}

The treatment of organic waste with fly larvae is a promising technology to reduce and recycle food waste responsible for unsanitary conditions encountered in urban areas into useful products. Fly larvae are used for biodegradation of multiple wastes, such as food/restaurant waste, meat processing waste, slaughterhouse waste, municipal garbage, agricultural waste, and market waste [25,31,40,50,60-62]. Moreover, bioconversion of waste with housefly larvae may result in significant production of feed ingredient as housefly larvae have a suitable nutritional composition and can serve as a replacement for fish meal and other protein sources used in poultry nutrition $[18,32-42,63]$. Insects are sensitive to many abiotic and biotic factors $[64,65]$. In particular, the life cycle parameters of $M$. domestica larvae are influenced by temperature, humidity, diet, and rearing density. The current study showed that the larval biomass and number of larvae on three rearing substrates were significantly influenced by egg load and substrate type. After 5 days of growth, larval biomass increased as a function of egg load for all substrates. The optimal biomass was obtained with an egg load of $10 \mathrm{mg}$ on wheat bran. Under the same nutritional conditions, the yield of housefly larvae and number of larvae increased with increasing breeding density. However, when breeding density continued to increase, yield tended to become stable $[8,37,40,66]$. At relatively high breeding densities, larvae cannot consume enough nutrients for growth and development, resulting in small individuals with incomplete development, or even death, leading to the stabilization or, even, decline in yield $[40,67,68]$. In particular, an egg load greater than 16 eggs/g of manure could lead to overpopulation, which would reduce larval biomass, due to insufficient nutrients being available for larval development [37]. An optimum larval density of $0.225 \mathrm{~g}$ CSMA (Chemical Specialties Manufacturers' Association) larval medium per egg was described in one study [69], but since these various densities on various substrates were explored $[27,44,48]$ with stocking densities mostly expressed per unit of feed source. For example, densities evaluated ranged from one larva per gram of poultry manure or cattle manure $[27,37,44]$ to 16 larva per gram $[37,48]$. However, larvae production was found to be closely correlated $(R>0.958)$ with stocking densities [27]. The optimum stocking density to obtain a significant quantity of pupae is $3 \mathrm{~g}$ of eggs per $4 \mathrm{~kg}$ of fresh poultry manure, while the density of $2 \mathrm{~g}$ of eggs per $4 \mathrm{~kg}$ of fresh manure results in individually larger larvae [48]. A later study [44] summarized the influence of temperature and density (uncrowded $=1$ larva/g manure; moderately crowded $=2.5$ larvae $/ g$ manure; crowded $=5$ larvae $/ g$ manure) with fastest larval development at $32{ }^{\circ} \mathrm{C}$. The most variation in larval size was observed in uncrowded larvae, and survival rates were the best at $23^{\circ} \mathrm{C}$ uncrowded. Pupal mass was highest for uncrowded larvae.

In the current study, wheat bran produced a higher larval biomass compared to cow dung and millet bran, regardless of egg load. These results were attributed to wheat bran having a loose, less consistent, and more aerated structure compared to cow dung and millet bran, which was more compact with high moisture loss. Several studies stated that maggot yield varies greatly with the characteristics of the substrate used, including odor, texture, decomposition rate, moisture holding capacity, and chemical composition [37,38,70-72].

In the present study survival rate from egg hatching until the last larval instar (SR) was influenced by substrate type. This difference could be explained by the low moisture holding capacity observed on millet bran. The different types of diets and their moisture content are factors that influence the development of M. domestica [73-75]. Low humidity causes water loss through the membrane of insect eggs, resulting in the desiccation and failure of embryos to hatch [54]. Females of many fly species, including the housefly, select spawning sites very carefully, preferentially laying eggs on surface structures with substrate characteristics that maximize offspring survival [76,77]. Spreading eggs over a substrate surface increases the risk that some eggs are placed in a location with favorable properties, reducing competition between larvae early in their development. Simple dispersal of eggs on substrate can increase larval survival, allowing higher larval biomass to be produced [71]. 
Substrate rate reduction (SRR) increased with increasing breeding density for all three substrates and was more pronounced on wheat bran. The optimum load of eggs for the biodegradation of different types of waste used was $10 \mathrm{mg} / 20 \mathrm{~g}$ substrate. This result was similar to that obtained by [37], who recorded an increasing rate of substrate reduction of $4.7 \%, 11.2 \%, 20.6 \%, 25.3 \%$, and $26.5 \%$ for egg loads of $1,2,4,8$, and 16 eggs/g manure, respectively. The authors concluded that higher egg loading enhanced biodegradation. [78] estimated that the optimum quantity of $\mathrm{M}$. domestica eggs for complete biodegradation was $0.4 \mathrm{~mL}(4400 \mathrm{eggs}) / \mathrm{kg}$ for a mixture of manure with sawdust and $1 \mathrm{~mL}(11,000 \mathrm{eggs}) / \mathrm{kg}$ for fresh manure. In comparison, [40] stated that the optimum egg load for complete biodegradation was $1.5 \mathrm{~g}(24,000 \mathrm{eggs}) / \mathrm{kg}$ for a mixture of food waste with wheat bran. However, the number of larvae converting a certain amount of food waste increased with increasing breeding density, leading to a relative lack of food for housefly larvae, forcing them to feed on foods with low nutritional value, such as vegetable protein and crude fiber to survive [66]. Therefore, breeding density contributes to the conversion rate of substrate. However, when breeding density noticeably increased, the average rate of substrate reduction decreased [67]. This phenomenon might be attributed to the excessive feeding density, which causes body weight to decline and hinders development in housefly larvae. This phenomenon reduces the feeding capacity and activity of larvae [52], and negatively affects larval yield and substrate rate reduction. Consequently, a moderate increase in breeding density could promote the conversion efficiency of housefly larvae to substrate.

\section{Conclusions}

This study contributes to the efficient use of fly maggots in waste treatment. Many advantages are linked to the waste management using the housefly which may well benefit poor African countries. To be efficient, larval density used to treat the waste should be controlled to increase larval yield and achieve effective and efficient waste reduction. Under the same nutritional conditions, the yield of housefly larvae, the number of larvae and the reduction of substrates increased with increasing egg load. At each of three substrates, the rearing egg load of $10 \mathrm{mg}$ resulted in the maximum larval yield, maximum number of larvae, and maximum substrate reduction rate. Larval density should be controlled to increase larval yield and obtain effective and efficient reduction in waste. Optimal larval density enhances the performance (efficiency and effectiveness) of biodegradation facilities and larval biomass production. Perhaps higher egg loads would have negatively impacted these parameters. This study probably did not reach the maximum production densities so it would be interesting to develop models to predict more increasing biomass depending on the substrates used.

Author Contributions: Conceptualization, I.H.L.; data curation, I.H.L.; funding acquisition, F.F.; methodology, I.H.L., Z.M.O. and R.C.M.; supervision, Z.M.O., F.F. and R.C.M.; formal analysis, I.H.L., G.N. and R.C.M.; writing original draft, I.H.L.; writing-review and editing, Z.M.O., G.N. and R.C.M. All authors have read and agreed to the published version of the manuscript.

Funding: This research received Belgium development cooperation (ARES-CCD) funding.

Institutional Review Board Statement: Not applicable.

Data Availability Statement: The data presented in this study are available in this article.

Acknowledgments: The authors are grateful to all those who contributed either way to complete this study.

Conflicts of Interest: The authors declare no conflict of interest. The funders had no role in the design of the study; in the collection, analyses, or interpretation of data; in the writing of the manuscript, or in the decision to publish the results. 


\section{References}

1. Kaza, S.; Yao, L.C.; Bhada-Tata, P.; Van Woderden, F. What a Waste 2.0: A Global Snapshot of Solid Waste Management to 2050; Urban development; World Bank: Washington, DC, USA, 2018.

2. Adamou, P.O. Diagnosis of the Household Solid Waste Management System of the 4th District of the City of Niamey (Niger) and Proposal of Improvement Solutions. Master's Thesis; Burkina Faso, 2015. Available online: www.secheresse.info/spip.php? article57509 (accessed on 3 August 2021).

3. Tini, A. Solid Waste Management in Niamey, Niger Trial for Sustainable Management Strategy. Ph.D. Thesis, Institute of Applied Sciences, Lyon, France, 2003.

4. United Nation. World Population Prospects-Population Division-United Nations. 2021. Available online: https://population. un.org/wpp/2021 (accessed on 3 August 2021).

5. Niger. Summary of the Results of the Pastoral Campaign 2015-2016: Draft Version; Ministry of Livestock: Niamey, Niger, 2015.

6. Aoike, U. Household waste and local solid waste collection in Niamey, Republique of Niger. Afr. Study Monogr. Suppl. 2019, 58, 93-114. [CrossRef]

7. Gao, A.; Tian, Z.; Wang, Z.; Wennersten, R.; Sun, Q. Comparison between the technologies for food waste treatment. Energy Procedia 2017, 105, 3915-3921. [CrossRef]

8. Cheng, J.Y.; Chiu, S.L.; Lo, I.M. Effects of moisture content of food waste on residue separation, larval growth and larval survival in black soldier fly bioconversion. Waste Manag. 2017, 67, 315-323. [CrossRef] [PubMed]

9. Van Huis, A. Potential of insects as food and feed in assuring food security. Annu. Rev. Entomol. 2013, 58, 563-583. [CrossRef]

10. Van Huis, A.; Oonincx, D.G.A.B. The environmental sustainability of insects as food and feed. A review. Agron. Sustain. Dev. 2017, 37, 43. [CrossRef]

11. Pastor, B.; Velásquez, Y.; Gobbi, P.; Rojo, S. Conversion of organic wastes into fly larval biomass: Bottlenecks and challenges. J. Insects Food Feed. 2015, 1, 179-193. [CrossRef]

12. Adeniji, A.A. Effect of replacing groundnut cake with maggot meal in the diet of broilers. Int. J. Poult. Sci. 2007, 6, 822-825. [CrossRef]

13. Bouafou, K.G.M. Revue bibliographique sur les asticots et leur emploi dans l'alimentation animale. J. Anim. Plant Sci. 2011, 12, 1543-1551.

14. Fasakin, E.A.; Balogun, A.M.; Ajayi, O.O. Evaluation of full-fat and defatted maggot meals in the feeding of clariid catfish Clarias gariepinus fingerlings. Aquac. Res. 2003, 34, 733-738. [CrossRef]

15. Henry, M.; Gasco, L.; Chatzifotis, S.; Piccolo, G. Does dietary insect meal affect the fish immune system? The case of mealworm, Tenebrio molitor on European sea bass, Dicentrarchus labrax. Dev. Comp. Immunol. 2018, 81, 204-209. [CrossRef]

16. Makkar, H.P.; Tran, G.; Heuzé, V.; Ankers, P. State-of-the-art on use of insects as animal feed. Anim. Feed. Sci. Technol. 2014, 197, 1-33. [CrossRef]

17. Moula, N.; Detilleux, J. A Meta-Analysis of the effects of insects in feed on poultry growth performances. Animals 2019, 9, 201. [CrossRef] [PubMed]

18. Ogunji, J.; Kloas, W.; Wirth, M.; Schulz, C.; Rennert, B. Housefly maggot meal (mag meal) as a protein source for Oreochromis niloticus (Linn). Asian Fish. Sci. 2008, 21, 319-331.

19. Pieterse, E.; Pretorius, Q. Nutritional evaluation of dried larvae and pupae meal of the housefly (Musca domestica) using chemicaland broiler-based biological assays. Anim. Prod. Sci. 2014, 54, 347-355. [CrossRef]

20. Van Huis, A.; Van Itterbeeck, J.; Klunder, H.; Mertens, E.; Halloran, A.; Muir, G.; Vantomme, P. Edible Insects: Future Prospects for Food and Feed Security; FAO forestry paper; Food and Agriculture Organization of the United Nations: Rome, Italy, 2013.

21. Bloukounon-Goubalan, A.Y.; Saïdou, A.; Obognon, N.; Amadji, G.L.; Igue, A.M.; Clottey, V.A.; Kenis, M. Decomposition and nutrient release pattern of animal manures biodegraded by fly larvae in Acrisols. Can. J. Soil Sci. 2019, 99, 60-69. [CrossRef]

22. Coulibaly, K.; Sankara, F.; Pousga, S.; Nacoulma, P.; Some, M.; Nacro, H. Effects of poultry litter and the residues of maggot's production on chemical fertility of a lixisol and maize (Zea mays L.) yield in western of Burkina Faso. Niger. J. Soil Sci. 2020, 30, 95-102.

23. Coulibaly, K.; Sankara, F.; Pousga, S.; Nacoulma, P.J.; Somé, M.B.; Nacro, H.B. On station maggot production using poultry-litter as substrate: Assessment on the quantity and the chemical quality of the litter before and after maggot production in Burkina Faso. Int. J. Biol. Chem. Sci. 2020, 14, 1689-1697. [CrossRef]

24. Wang, H.; Wang, S.; Li, H.; Wang, B.; Zhou, Q.; Zhang, X.; Li, J.; Zhang, Z. Decomposition and humification of dissolved organic matter in swine manure during housefly larvae composting. Waste Manag. Res. 2016, 34, 465-473. [CrossRef]

25. Zhang, Z.; Wang, H.; Zhu, J.; Suneethi, S.; Zheng, J. Swine manure vermicomposting via housefly larvae (Musca domestica): The dynamics of biochemical and microbial features. Bioresour. Technol. 2012, 118, 563-571. [CrossRef]

26. Fowles, T.M.; Nansen, C. Insect-Based Bioconversion: Value from Food Waste; Palgrave Macmillan: Cham, Switzerland, 2019; pp. 321-346. [CrossRef]

27. Barnard, D.; Harms, R.; Sloan, D. Biodegradation of poultry manure by house fly (Diptera: Muscidae). Environ. Entomol. 1998, 27, 600-605. [CrossRef]

28. Koo, S.; Currin, T.; Johson, M.; King, E.; Turk, D. La valeur nutritive et la teneur microbienne des pupes séchées de mouche de visage (Musca autumnalis (De Geer)) une fois alimentées aux poussins. Poult. Sci. 1998, 59, 2514-2518. [CrossRef] 
29. Roffeis, M.; Muys, B.; Almeida, J.; Mathijs, E.; Achten, W.; Pastor, B.; Velásquez, Y.; Martínez-Sánchez, A.; Rojo, S. Pig manure treatment with housefly (Musca domestica) rearing-An environmental life cycle assessment. J. Insects Food Feed. 2015, 1, 195-214. [CrossRef]

30. Surendra, K.; Olivier, R.; Tomberlin, J.K.; Jha, R.; Khanal, S.K. Bioconversion of organic wastes into biodiesel and animal feed via insect farming. Renew. Energy 2016, 98, 197-202. [CrossRef]

31. Yehuda, B.; Marchaim, U.; Glatman, L.; Drabkin, V.; Chizov-Ginzburg, A.; Mumcuoglu, K.Y.; Gelman, A. Bioconversion of poultry and fish waste by Lucilia sericata and Sarcophaga carnaria larvae. Asian J. Water Environ. Pollut. 2011, 8, 69-75.

32. Abraham, K.O.; Richard, A.A.; Aihoon, S. Proximate composition of housefly (Musca domestica) maggots cultured on different substrates as potential feed for Tilapia (Oreochromis niloticus). Int. J. Multidiscip. Res. Dev. 2015, 2, 102-103.

33. Arong, G.A.; Eyo, V.O. Evaluation of housefly (Musca domestica) maggot meal and termite (Macrotermes subhyalinus) meal as supplementary feed for african catfish Clarias gariepinus (Burchell, 1822). Int. J. Entomol. Nematol. 2017, 3, 43-50.

34. Djissou, A.S.M.; Tossavi, E.C.; Vodounnou, J.D.; Toguyeni, A.; Fiogbe, E.D. Valorization of agro-alimentary waste for a production of maggots like source of proteins in the animal feeds. Int. J. Agron. Agric. Res. 2015, 7, 42-46.

35. Ekoue, S.E.; Hadzi, Y.A. Production d'asticots comme source de protéines pour jeunes volailles au Togo-Observations préliminaires. Tropicultura 2000, 18, 2012-2014.

36. Ezewudo, B.I.; Moneb, C.O.; Ugwumba, A.A.A. Production and utilization of Musca domestica maggots in the diet of Oreochromis niloticus (Linnaeus, 1758) fingerlings. Afr. J. Agric. Res. 2015, 10, 2363-2371. [CrossRef]

37. Hussein, M.; Pillai, V.V.; Goddard, J.M.; Park, H.G.; Kothapalli, K.S.; Ross, D.A.; Ketterings, Q.M.; Brenna, J.T.; Milstein, M.B.; Marquis, H.; et al. Sustainable production of housefly (Musca domestica) larvae as a protein-rich feed ingredient by utilizing cattle manure. PLoS ONE 2017, 12, e0171708. [CrossRef]

38. Koné, N.; Sylla, M.; Nacambo, S.; Kenis, M. Production of Housefly larvae for animal feed through natural oviposition. J. Insects Food Feed 2017, 3, 177-186. [CrossRef]

39. Mpoame, M.; Téguia, A.; Nguemfo, E.L. Essai comparé de production d'asticots dans les fientes de poule et dans la bouse de vache. Tropicultura 2004, 22, 84-87.

40. Niu, Y.; Heng, D.; Yao, B.; Cai, Z.; Zhao, Z.; Wu, S.; Cong, P.; Yang, D. A novel bioconversion for value-added products from food waste using Musca domestica. Sci. Directs 2017, 61, 455-460. [CrossRef] [PubMed]

41. Odesanya, B.O.; Ajayi, S.O.; Agbaogun, B.K.O.; Okuneye, B. Comparative evaluation of nutritive value of maggots. Int. J. Sci. Eng. Res. 2011, 2, 1-5.

42. Tobin, P.; Pitts, C.W. Geostatistical analysis and the impact of moisture on the spatial and temporal distribution of larval Musca domestica (Diptera: Muscidae). Environ. Entomol. 2002, 31, 273-280. [CrossRef]

43. Leyo, I.H.; Ousman, Z.M.; Francis, F.; Megido, R.C. Techniques de production d'asticots de mouches domestiques (Musca domestica L. 1758) pour l'alimentation des volailles, synthèse bibliographique. Trop 2021. [CrossRef]

44. Barnard, D.R.; Geden, C.J. Influence of larval density and temperature in poultry manure on development of the house fly (Diptera: Muscidae). Environ. Entomol. 1993, 22, 971-977. [CrossRef]

45. Bellows, T.S. The descriptive properties of some models for density dependence. J. Anim. Ecol. 1981, 50, 139. [CrossRef]

46. Pieterse, E.; Gloy, E. Determination of the influence of a constant nutrient supply on wet yield, dry yield and average weight of Musca domestica larvae maintained at different densities. Afr. Entomol. 2013, 21, 239-242. [CrossRef]

47. Sullivan, R.L.; Sokal, R.R. The effects of larval density on several strains of the house fly. Ecology 1963, 44, 120-130. [CrossRef]

48. Teotia, J.S.; Miller, B.F. Environmental conditions affecting development of house fly larvae in poultry manure. Environ. Entomol. 1973, 2, 329-334. [CrossRef]

49. Kenis, M.; Koné, N.; Chrysostome, C.; Devic, E.; Koko, G.; Clottey, V.; Nacambo, S.; Mensah, G. Insects used for animal feed in West Africa. Entomologia 2014, 2. [CrossRef]

50. Aniebo, A.O.; Erondu, E.S.; Owen, O.J. Proximate composition of housefly larvae (Musca domestica) meal generated from mixture of cattle blood and wheat bran. Livest. Res. Rural Dev. 2008, 20, 1-5.

51. Hwangbo, J.; Hong, E.C.; Jan, A.; Kang, H.K.; Oh, J.S.; Kim, B.W.; Park, B.S. Utilization of housefly-maggots, a feed supplement in the production of broiler chickens. J. Environ. Biol. 2009, 30, 609-614. [PubMed]

52. Wang, H.; Zhang, Z.; Czapar, G.F.; Winkler, M.K.; Zheng, J. A full-ccale house fly (Diptera: Muscidae) larvae bioconversion system for value-added swine manure reduction. Waste Manag. Res. J. Sustain. Circ. Econ. 2013, 31, 223-231. [CrossRef] [PubMed]

53. Recensement, G.A.C. Analyse Des Résultats Des Enquêtes Sur Les Marches à Bétail et Le Cheptel Aviaire. Projet GCP/NER/041/EC; Ministère du Développement Agricole, Ministère des Ressources Animales, Union européenne, FAO: Abuja, Niger, $2008 ;$ p. 85.

54. Holmes, L.A.; VanLaerhoven, S.L.; Tomberlin, J.K. Relative humidity effects on the life history of Hermetia illucens (Diptera: Stratiomyidae). Environ. Entomol. 2012, 41, 971-978. [CrossRef]

55. Keiding, J.; Arevad, K. Procedure and equipment for rearing a large number of housefly strains. Bull. World Heal. Organ. 1964, 31, 527-528.

56. Meneguz, M.; Schiavone, A.; Gai, F.; Dama, A.; Lussiana, C.; Renna, M.; Gasco, L. Effect of rearing substrate on growth performance, waste reduction efficiency and chemical composition of black soldier fly (Hermetia illucens) larvae. J. Sci. Food Agric. 2018, 98, 5776-5784. [CrossRef]

57. R. Core Team. A Language and Environment for Statistical Computing; R Foundation for Statistical Computing: Vienna, Austria, 2021. 
58. De Mendiburu, D.F. Una Herramienta de Análisis Estadístico para la Investigación Agrícola. Master's Thesis, Universidad Nacional de Ingenieria (UNI-PERU), Lima, Peru, 2009. Available online: http://cybertesis.uni.edu.pe/handle/uni/14814 (accessed on 3 August 2021).

59. Lê, S.; Josse, J.; Husson, F. FactoMineR: An R Package for multivariate analysis. J. Stat. Softw. 2008, 25, 1-18. [CrossRef]

60. Diener, S.; Studt Solano, N.M.; Roa Gutiérrez, F.; Zurbrügg, C.; Tockner, K. Biological treatment of municipal organic waste using black soldier fly larvae. Waste Biomass Valorizat. 2011, 2, 357-363. [CrossRef]

61. Hem, S.; Touré, S.; Sagbla, S.; Legendre, M. Bioconversion of palm kernel meal for aquaculture: Experiences from the forest region (Republic of Guinea). Afr. J. Biotechnol. 2008, 7, 1192-1198.

62. Yang, D.; Huang, M.; Liang, D.; Li, Z.; Yang, W. Biodiesel and Preparation Method. Thereof. Patent US20120144732A1, 14 June 2012.

63. Agunbiade, J.A.; Adeyemi, O.; Ashiru, O.M.; Awojobi, H.A.; Taiwo, A.A.; Oke, D.B.; Adekunmisi, A.A. Replacement of fish meal with maggot meal in cassava-based layers' diets. J. Poult. Sci. 2007, 44, 278-282. [CrossRef]

64. Barragan-Fonseca, K.B.; Dicke, M.; Van Loon, J.J. Influence of larval density and dietary nutrient concentration on performance, body protein, and fat contents of black soldier fly larvae (Hermetia illucens). Entomol. Exp. Appl. 2018, 166, 761-770. [CrossRef] [PubMed]

65. Dzepe, D.; Nana, P.; Fotso, A.; Tchuinkam, T.; Djouaka, R. Influence of larval density, substrate moisture content and feedstock ratio on life history traits of black soldier fly larvae. J. Insects Food Feed. 2020, 6, 133-140. [CrossRef]

66. Čičková, H.; Newton, G.L.; Lacy, R.C.; Kozánek, M. The use of fly larvae for organic waste treatment. Waste Manag. 2015, 35, 68-80. [CrossRef]

67. Cheng, Z.; Yu, L.; Li, H.; Xu, X.; Yang, Z. Use of housefly (Musca domestica L.) larvae to bioconversion food waste for animal nutrition and organic fertilizer. Environ. Sci. Pollut. Res. 2021, 28, 48921-48928. [CrossRef]

68. Green, P.; Simmonds, M.S.; Blaney, W.M. Diet nutriment and rearing density affect the growth of black blowfly larvae, Phomia regina (Diptera: Calliphoridae). Eur. J. Entomol. 2003, 100, 39-42. [CrossRef]

69. Bryant, E.H.; McCommas, A.S.; Combs, L.M. The effect of an experimental bottleneck upon quantitative genetic variation in the housefly. Genetics 1986, 114, 1191-1211. [CrossRef]

70. Bouafou, K.G.M.; Kouame, K.G.; Amoikon, K.E.; Offoumou, A.M. Potentiel pour la production d'asticots sur des sous-produits en Côte d'Ivoire. Trop 2006, 24, 157-161.

71. Čičková, H.; Kozánek, M.; Takáč, P. Improvement of survival of the house fly (Musca domestica L.) larvae under mass-rearing conditions. Bull. Entomol. Res. 2012, 103, 119-125. [CrossRef]

72. Sanou, A.G.; Sankara, F.; Pousga, S.; Coulibaly, K.; Nacoulma, J.P.; Ouedraogo, I.; Nacro, S.; Kenis, M.; Sanon, A.; Somda, I. Production de masse de larves de Musca domestica L. (Diptera: Muscidae) pour l'aviculture au Burkina Faso: Analyse des facteurs déterminants en oviposition naturelle. J. Appl. Biosci. 2019, 134, 13689-13701. [CrossRef]

73. Bauer, A.; Bauer, A.M.; Tomberlin, J.K. Impact of diet moisture on the development of the forensically important blow fly Cochliomyia macellaria (Fabricius) (Diptera: Calliphoridae). Forensic Sci. Int. 2020, 312, 110333. [CrossRef] [PubMed]

74. Chia, S.; Tanga, C.M.; Khamis, F.M.; Mohamed, S.A.; Salifu, D.; Sevgan, S.; Fiaboe, K.K.M.; Niassy, S.; Van Loon, J.J.A.; Dicke, M.; et al. Threshold temperatures and thermal requirements of black soldier fly Hermetia illucens: Implications for mass production. PLoS ONE 2018, 13, e0206097. [CrossRef]

75. Kökdener, M. Impact of diet and moisture content on the development of Musca domestica (Diptera: Muscidae). Environ. Entomol. 2021, 50, 399-404. [CrossRef] [PubMed]

76. Pastor, B.; Čičková, H.; Kozánek, M.; Martínez-Sánchez, A.; Takáč, P.; Rojo, S. Effect of the size of the pupae, adult diet, oviposition substrate and adult population density on egg production in Musca domestica (Diptera: Muscidae). Eur. J. Entomol. 2011, 108, 587-596. [CrossRef]

77. Ward, P.I.; Foglia, M.; Blanckenhorn, W.U. Oviposition site choice in the yellow dung fly Scathophaga stercoraria. Ethology 2001, 105, 423-430. [CrossRef]

78. Čičková, H.; Pastor, B.; Kozánek, M.; Martínez-Sánchez, A.; Rojo, S.; Takáč, P. Biodegradation of pig manure by the housefly, Musca domestica: A viable ecological strategy for pig manure management. PLoS ONE 2012, 7, e32798. [CrossRef] 